\title{
A Radiocarbon Date from the Coker Mound (41CS1)
}

Timothy K. Perttula

Heritage Research Center, Stephen F. Austin State University

Mike Turner

Bo Nelson

Heritage Research Center, Stephen F. Austin State University

Follow this and additional works at: https://scholarworks.sfasu.edu/ita

Part of the American Material Culture Commons, Archaeological Anthropology Commons, Environmental Studies Commons, Other American Studies Commons, Other Arts and Humanities Commons, Other History of Art, Architecture, and Archaeology Commons, and the United States History Commons

Tell us how this article helped you.

This Article is brought to you for free and open access by the Center for Regional Heritage Research at SFA ScholarWorks. It has been accepted for inclusion in Index of Texas Archaeology: Open Access Gray Literature from the Lone Star State by an authorized editor of SFA ScholarWorks. For more information, please contact cdsscholarworks@sfasu.edu. 


\section{A Radiocarbon Date from the Coker Mound (41CS1)}

Creative Commons License

(c) (i) (8)

This work is licensed under a Creative Commons Attribution-NonCommercial 4.0 International License 


\title{
A RADIOCARBON DATE FROM THE COKER MOUND (41CS1)
}

\author{
Timothy K. Perttula, Mike Turner, and Bo Nelson
}

The Coker Mound (4ICS1) on the Sulphur River is one of the more poorly known Caddoan mound sites in Northeast Texas. Recorded and tested by the University of Texas in 1932 (Jackson 1932), the work done then at a conical mound at the site did not clearly establish either the function of the mound, its age, or its cultural affiliations with other prehistoric Caddoan groups in the region.

Jackson's (1932) trenching did suggest that this conical mound was built by Caddoan groups because Caddoan sherds were recovered from several different strata within the mound (particularly in a dense bone- and shell-filled midden and charcoal-rich deposit between $39-85 \mathrm{~cm}$ below surface), and in the A-horizon of the natural soil immediately below the $1.72 \mathrm{~m}$ thick mound. A single broken stemmed arrow point was also recovered about $1.08 \mathrm{~m}$ deep in the mound. No provenience was kept for the sherds within the mound, however, which might now have further clarified the age of the mound deposits. There is a large collection of sherds $(n=471)$ that Jackson picked up from the surface around the Coker Mound (see below) that warrants further consideration.

The $2.2 \mathrm{~m}$ deep, $21.6 \mathrm{~m}$ long, and $2.6 \mathrm{~m}$ wide trench dug by Jackson (1932) near the center of the Coker Mound disclosed no structures or burials. Charcoal, ashes, bones, mussel shells, and ceramic sherds were present throughout the mound, and in the Ahorizon below it, suggesting to Jackson (1932) that the mound was built up from domiciliary use, further suggesting that the source of the mound fill was nearby midden deposits scooped up off the site itself. An apparent large $(1.8 \times 1.2 \mathrm{~m})$ ash feature was noted near the center of the mound, between about 31-61 cm below surface, and although Jackson (1932:5) commented no further about it, we suspect that the ash feature probably relates to a hearth within a Caddoan structure buried in the mound.

This was all we knew about the Coker Mound until a few years ago, when we leamed that the Coker Mound was being dug into by unknown individuals, and that during this work (at one of the four apparent mounds on the site), a deposit of burials (supposedly in three layers), ceramic vessels, and conch shell artifacts was located. Through the efforts of Mike Turner, a small portion of the collections from the mound has been documented, including a black-slipped bottle similar to the Haley Engraved type, and a Caddoan skull with cranial modeling (cf. Derrick and Wilson 1997).

We felt it was important to attempt to more definitively establish the chronological context of the Caddoan occupation at the Coker Mound, which appeared on the basis of the engraved bottle to date to the Middle Caddoan period, ca. A.D. 1200-1400 (see Cliff 1996). Accordingly, a radiocarbon sample of a single human vertebra was submitted to Beta Analytic, Inc. from one of the burials in the mortuary deposit. We present the results of the recently obtained radiocarbon date in this paper.

Because of the small size of the Feature 2 sample, the radiocarbon sample was analyzed by Beta Analytic, Inc. at an accelerator mass spectrometer (AMS) at the Lawrence-Livermore National Laboratory in Berkeley, California. The measured radiocarbon age of the collagen in the human vertebra is $410 \pm 50$ years before present (BP) (Beta-92919). After applying the $\mathrm{C} 13 / \mathrm{C} 12$ ratio (-14.6 o/oo from the bone collagen) carbon corrections to the measured age, the conventional and uncalibrated radiocarbon age of the AMS sample is $570 \pm 50 \mathrm{BP}$, or A.D. 1330-1430.

Using the Pretoria Calibration Procedure program (Vogel et al. 1993), there is a $68 \%$ probability (one sigma) that the calibrated AMS date from the vertebra falls between either A.D. 1315-1345 and A.D. 1390-1420, with a cal AD 1405 intercept. At two sigma (or 95\% probability), the calibrated date for the vertebra is A.D. 1300-1435.

Both the one and two sigma dates are consistent with the human vertebra being of Middle Caddoan period age. The age of the vertebra seems reasonable given what is known 
about the archaeological associations, namely the engraved bottle and the Jackson (1932) ceramic surface collection from around the mound.

The bottle is dark brown to black in color, obviously fired in a reducing environment, and it is well polished. It has a pear-shaped body with a slightly tapering neck and a flat base (Figure 1), a vessel form characteristic of the latter part of the Middle Caddoan period as suggested by Bohannon's (1973:57) seriation of vessel modes from the Mineral Springs (3HO1) mound site. The first element of the engraved decoration consists of two horizontal lines around the base of the bottle neck, and a third horizontal line with large pendant triangles themselves formed by a series of closely spaced lines. The outside of the pendant triangles and the bottom horizontal line have small excised ticks or spurs, a common feature of Haley Engraved bottles (Suhm and Jelks 1962:61). The second decorative element, which covers the body, are a series of evenly spaced concentric engraved arcs, with the central engraved line marked by a series of excised ticks or spurs (see Figure 1). The final decorative element occurs near the base of the bottle. It is comprised of three engraved semi-circles with excised ticks or spurs centered under the crest of the engraved arcs covering the body. The engraved decoration on the bottle is filled with a white kaolin clay pigment.

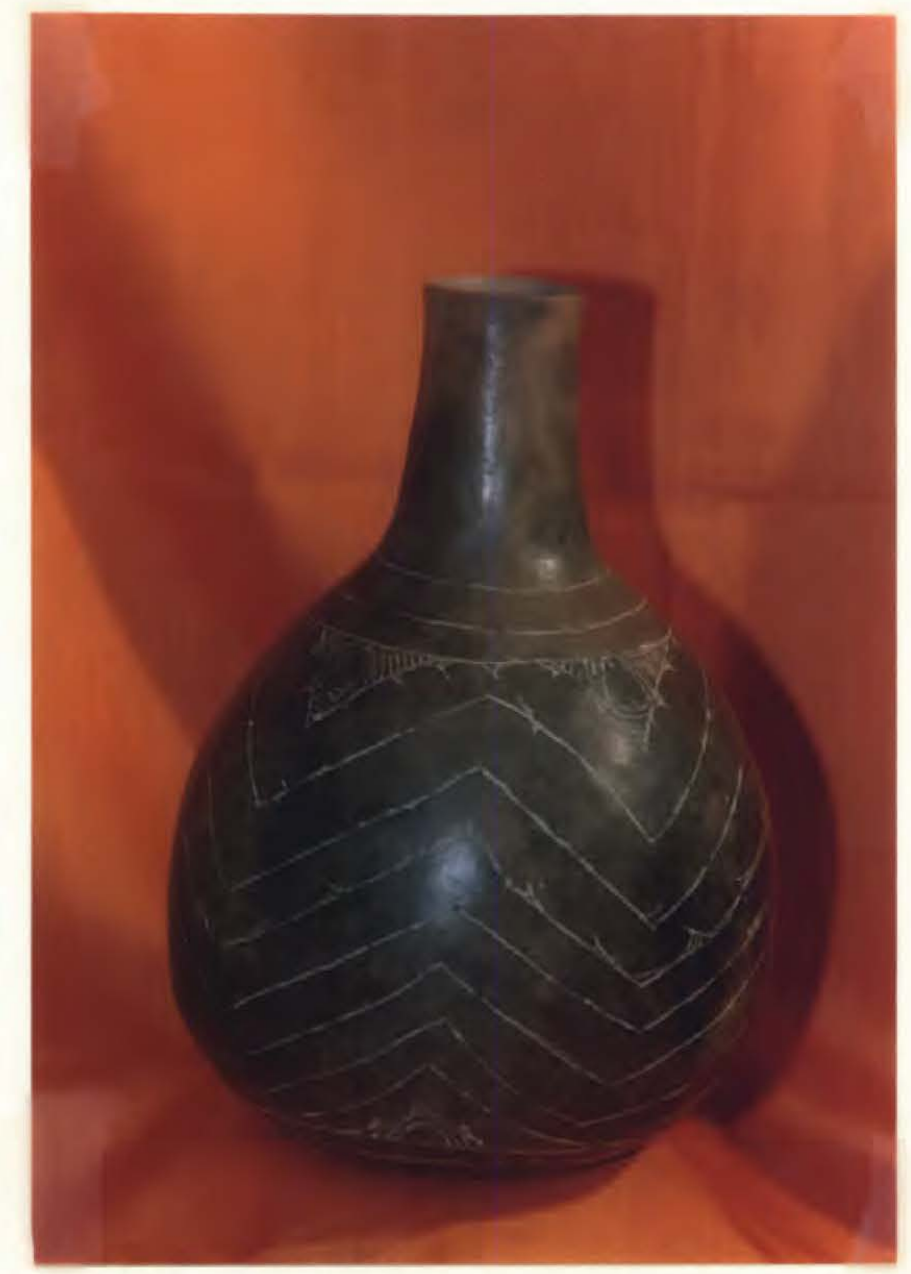

Figure 1. An Engraved Bottle from the Coker Mound (41CS1).

The sherd collection from the surface around the mound includes 350 plain body and base sherds, including 14 that are relatively thick and may be from Williams Plain vessels, 55 plain red-slipped sherds, and 66 mostly non-descript and small decorated sherds (Story 1987). Among the latter are 20 incised, 12 punctated, 12 brushed, 12 
engraved (five of the engraved sherds are from red-slipped vessels), seven applique, one neck-banded, one punctated-incised, and one pinched. Story (1987) suggested that five of the applique sherds may be from Pease Brushed-Incised jars, a common utility ware ceramic in the lower Sulphur River area after A.D. 1300 (e.g., Cliff 1996). None of the other decorated sherds were apparently typeable. To us, there are several notable features of this small surface-collected ceramic assemblage that strongly hints of its Middle Caddoan period temporal association: (a) the high frequency of red-slipping (12 percent of the collection);(b) the presence of brushed ceramics $(n=12)$, but the dominance of incised and punctated sherds $(n=33)$; and (c) the presence of Pease Brushed-Incised sherds.

The use of one of the mounds at the Coker Mound site for burials during the Middle Caddoan period is the first incontrovertible evidence that there were mounds being built and used in the lower Sulphur River area of Northeast Texas during this time (see Cliff 1996, and this volume). The date also documents a form of mortuary practice---the placement of burials within an earthen mound--that, while known from Middle Caddoan contexts at the mouth of the Sulphur River and widespread in major Caddoan communities along the Great Bend of the Red River, was not previously known in the lower Sulphur River area.

The stable carbon isotope delta C13 value of -14.6 o/oo from the human vertebra indicates that the diet of this individual buried at the Coker Mound was based on a significant contribution of C4 plants, primarily maize. Stable carbon values ranging from -15.88 o/oo to -11.27 o/oo have been obtained on more than 50 individuals in Red River and Ouachita River Caddoan populations dating between ca. A.D. 1300 to after ca. A.D. 1650 , and constitute good evidence for the post-A.D. 1300 development of an agricultural economy in these areas (Perttula 1996). Stable carbon isotope values indicative of a non-C4 $\operatorname{diet}$ (ranging between $-21.95 \mathrm{o} / \mathrm{oo}$ and $-19.78 \mathrm{o} / \mathrm{oo}$ ) have been consistently obtained from Late Archaic, Fourche Maline/Woodland, and Caddoan populations that lived before ca. A.D. 1100. The Coker Mound individual, then, seems to have had the same diet as Caddoan neighbors living along the Red River in Louisiana, Arkansas, Oklahoma, and Texas, and in the Ouachita River drainage of Southwest Arkansas.

Provided permission can be obtained from the landowner, we intend over the next year to further investigate the archeological deposits at the Coker Mound. Of the utmost importance is to thoroughly examine the mound that contains the mortuary deposit, principally by cleaning and profiling the holes already dug into the mound, identifying mortuary and non-mortuary features within the mound, and securing radiocarbon and Oxidizable Carbon Ratio (Frink 1994) samples for additional dates from controlled contexts. We also wish to determine how many other mounds there are on the site, as well as their function and age, and learn if there are any associated habitation areas at Coker Mounds.

\section{References Cited}

Bohannon, C. F.

1973 Excavations at the Mineral Springs Site, Howard County, Arkansas. Research Series No. 5. Arkansas Archeological Survey, Fayetteville.

Cliff, M. B.

1996 The Middle Caddo Period in the Lower Sulphur River Area. In Symposium: "The Middle Caddo Period in East Texas." Paper presented at the Annual Meeting of the Texas Archeological Society, San Antonio.

Derrick, S. M. and D. E. Wilson

1997 Cranial Modeling as an Ethnic Marker among the Prehistoric Caddo. Bulletin of the Texas Archeological Society 68, in press. 
Frink, D. S.

1994 The Oxidizable Carbon Ratio (OCR): A Proposed Solution to Some of the Problems Encountered with Radiocarbon Data. North American Archaeologist 15(1):17-29.

Jackson, A. T.

1932 Earthen Mound on E. A. Coker Farm. MS on file, Texas Archeological Research Laboratory, The University of Texas at Austin.

Perttula, T. K.

1996 Caddoan Area Archaeology Since 1990. Journal of Archaeological Research 4 (No. 4):295-348.

Story, D. A.

1987 Analysis Notes and U.T. Austin Specimen Inventory Forms, the E. A. Coker Farm (41CS1). Records on file at the Texas Archeological Research Laboratory, The University of Texas at Austin.

Suhm, D. A. and E. B. Jelks (editors)

1962 Handbook of Texas Archeology: Type Descriptions. Special Publication No. 1, Texas Archeological Society, and Bulletin No. 4, Texas Memorial Museum, Austin.

Vogel, J. C., A. Fuls, E. Visser, and B. Becker

1993 Pretoria Calibration Curve for Short Lived Samples. Radiocarbon 35(1):73-86. 